\title{
A Quantitative Analysis of Indonesian Junior High School Science Textbooks for Scientific Literacy Themes
}

\author{
Adinda Regiliani Agustin ${ }^{1, *}$ Supahar $^{2}$ \\ ${ }^{l}$ Master of Natural Science Education, Faculty of Mathematics and Natural Sciences, Universitas Negeri Yogyakarta, \\ Indonesia \\ ${ }^{2}$ Department of Physics Education, Faculty of Mathematics and Natural Sciences, Universitas Negeri Yogyakarta, \\ Indonesia \\ *Corresponding author. E-mail: adindaregiliani.2019@student.uny.ac.id
}

\begin{abstract}
Textbooks have been used as learning tools to convey more information to students. The selected textbooks are used to support student and teacher textbooks published by the Ministry of Education and Culture of the Republic of Indonesia. The purpose of this study was to analyze aspects of scientific literacy themes in science textbooks. This study examines - through content analysis methods for Indonesian Secondary Education science textbooks concerning the Indonesian Curriculum 2013 on scientific literacy. The population was all pages of material in the junior high school science textbook for grades VII, VIII, and IX in the 2013 curriculum. Sampling was carried out using multistage sampling techniques in 2 stages. The results of the quantitative analysis carried out on textbooks conclude that Indonesian science textbooks focus on the "the knowledge of science" aspect, while the other three aspects of scientific literacy have an unbalanced proportion.
\end{abstract}

Keywords: Science education, Textbook, Scientific literacy

\section{INTRODUCTION}

Education has an important meaning as the basis of human life. Education's defined as an effort to increase human dignity and as a means to enhance the quality of human life to a higher level to ensure the implementation and continuity of development. Science education itself has the main goal of being able to help students in building concepts and construction of students' scientific characteristics, helping to develop scientific research processes so that students understand the concepts of science, natural phenomena, and their changes, and understand the relationship the social phenomena that occur with science so that it is expected students have an awareness of the importance of scientific literacy [1,2].

Scientific literacy is a multi-dimensional ability that includes knowledge, skill, disposition, a good relationship between science-technology-society (STS), history of science and its development, and the nature of science that students must have in questions, solve scientific problems, draw from the evidence, and make socio-scientific decisions that are relevant to everyday life $[4,5,6]$. Indonesia has made improvements from the KTSP curriculum to the 2013 curriculum. The 2013 curriculum demands itself to be designed for the implementation of scientific literacy in learning. This is the officer so that students gain closer knowledge and experience.

Concerning scientific literacy in the 2013 Curriculum, it shows the fact that Indonesian students have very low scientific literacy skills. From the results of the scientific literacy test compiled by PISA 2018, scientific literacy skills of students in Indonesia, especially students aged \pm 15 years, get an average value of 396, which is a decrease compared to the results of the 2015 PISA survey which scored 403 and an average score OCED of 489 [6].

Most students in Indonesia (41\%) are only able to get results at level 1, which indicates that students in Indonesia have limited knowledge of science, this 
knowledge can only be applied by students to several situations and simple problems that are familiar to students [7]. This is in line with the research results, overall only $55 \%$ of students can answer scientific literacy problems at a low cognitive level [8]. This represents that junior high school students in Bandung Indonesia have scientific literacy results that match the results of the Indonesian PISA science literacy test, which are still at a low level. The low level of scientific literacy in Indonesia is closely related to the gap between the current curriculum and its implementation in science learning in schools.

One of the factors that can lead to low student scientific literacy is the learning process that has not instinctively facilitated the learning process including science textbooks. School educators and science researchers have the same opinion that textbooks play an important part in teaching and learning activities for students [9]. Textbooks must be part of learning activities at school as well as individually for students, besides that the teacher can also use textbooks in all stages of learning and a variety of different learning methods. Textbooks also explain the relationship between scientific phenomena in the real world, scientific theories that explain them and can also be used as basic guidelines for teaching procedures for teachers in determining the content to be taught to students [10]. In line with this, the results of previous studies show that most science teachers $(90 \%)$ rely on textbooks in $95 \%$ of their teaching activities, thus the textbook becomes an outline of learning activities, the teacher's framework, the parameters for student experience and testing, and provides the student's worldview of science [11].

It should be realized that insufficient, inconsistent and weak student knowledge contained in science textbooks will give a loss in the development of students 'scientific ideas, thus causing misconceptions of science inherent in students' memories [12]. Previous research on science textbooks shows that the themes of scientific literacy content in junior high school textbooks in Indonesia are still dominated by aspects of scientific knowledge [13]. The level of content on the theme of scientific literacy in the three physics textbooks from the results of other studies concluded that the category of scientific knowledge was the most dominant category, while science was a way of thinking, science was a way of investigating and interacting science with technology and social society, there is not much contribution in the textbook.

Textbooks are used more often as the main source of information than any other teaching tool in many subjects, so it is important to maintain the quality of the textbook content accuracy in order to maintain the effectiveness of the transfer of knowledge to students [14]. So it is important to do research, analysis of science textbooks to ensure the accuracy and quality of science textbooks in accordance with the 2013 Curriculum in Indonesia. The purpose of conducting research on this matter is to determine the balance of content and proportions of scientific literacy themes in science textbooks for junior high schools in Indonesia related to the 2013 curriculum.

The classification in this study uses the aspects in the category as a guide in the framework of the analysis of science textbooks adopted from the research developed by Chiapetta, Fillman, and Sethna (1991) which consisted of four distinct categories in scientific literacy analysis. The four categories of scientific literacy that will be used are (1) science as a body of knowledge, (2) science as a way of carrying out an investigation (the investigative nature of science), (3) science as a way of thinking, (4) science and interaction with technology and society (STS) [15]. Meanwhile, the category of scientific literacy contained in textbooks must approach a balanced proportion, namely $42 \%$ in the category of scientific knowledge; $19 \%$ in the science trait inquiry category; $19 \%$ in the science as a way of thinking category, and $20 \%$ in the science and interaction with technology and society (STS) category [16]. According to the above statement, we can take a benchmark for this research if the proportion of science literacy in science textbooks for junior high schools in Indonesia can be utilized in the design of improving the quality of the preparation and writing of better textbooks in the future.

There are not many representations of scientific literacy analysis in science textbooks Curriculum 2013, To follow up on this, analysis-based research was conducted to analyze the representation of the themes in scientific literacy contained in textbooks adapted to the 2013 Curriculum. The research results are expected to contribute to efforts to increase the representation of scientific literacy in science textbooks for junior high schools in Indonesia in accordance with the curriculum that has been implemented.

\section{RESEARCH METHODS}

In this study, using a qualitative descriptive research method with document content analysis research methods. The population used in the study were all pages of material in class VII, VIII, and IX IPA textbooks according to the 2013 Curriculum. Each class used 2 different books. The sample used is several pages taken 
randomly in the textbook. The elements of the book analyzed in this content analysis include complete paragraphs, student evaluation questions or student thinking skills questions, pictures equipped with explanations, table with notes, supplementary information or additional information about certain figures, discoveries or history, and instructions regarding laboratory activities or simple practicum activities. Representations of scientific literacy in selected textbooks will be analyzed systematically and structurally according to the instruments that have been prepared in the form of a scientific literacy framework adapted from Chiapetta, Fillman \& Sethna (1991), as shown in Table 1.

Some of the text books that were selected for analysis were textbooks that were in accordance with the 2013 Curriculum which were compiled according to the instructions of the Ministry of Education and Culture of the Republic of Indonesia. This book is a book published by several non-governmental publishers used by students in Indonesia as a companion or complement to the Student Book which is officially published by the Ministry of Education.

Sampling was carried out by a multistage sampling technique, namely, samples were taken in 2 stages. The first stage, the chapters analyzed were taken at $20 \%$ of each number of chapters in the textbook which were taken randomly. In the second stage, the pages analyzed are selected from $20 \%$ of the total pages of each chapter selected in the first stage. Incomplete paragraphs are analyzed from the beginning of the paragraph, either looking at the previous page or after it. The pages analyzed are read and each paragraph within the page will be identified and classified according to aspects of scientific literacy.

The data obtained from the classification of textbook analysis into scientific literacy categories is included in the checklist of 2 observers on the observation table of scientific literacy indicators, the observer will give a checkmark $(\sqrt{ })$ in the appropriate column. The rubrics used in the analysis of this research are the categories "YES" and "NO". So that the points obtained $1=$ according to the description of scientific literacy indicators which are categorized while points $0=$ not following the description of scientific literacy indicators. The data from the table obtained were entered into the agreement contingency table. The calculation of the percentage occurrence of scientific literacy indicators is calculated for each category that arises from the analysis.

Table 1. Descriptions of Category of Scientific Literacy Used as a Framework for Textbook Analysis. Adapted from Chiapetta, Fillman, and Sethna (1991): A Method to Quantify Major Themes of Scientific Literacy in Science Textbooks.

\begin{tabular}{|l|l|l|}
\hline No & $\begin{array}{c}\text { Category of } \\
\text { Scientific Literacy }\end{array}$ & \\
\hline 1. & $\begin{array}{l}\text { The knowledge of } \\
\text { science }\end{array}$ & $\begin{array}{l}\text { Receiving information as part of the transmission of scientific knowledge by remembering, } \\
\text { presenting, or discussing some information, facts, concepts, principles, and laws that are } \\
\text { known to students. In this category the scientific literacy analyzed in books is divided into } \\
\text { several aspects as follows: } \\
\text { (a) It presents various facts, contains concepts, contains principles, and presents the laws of } \\
\text { science, } \\
\text { (b) include the hypothesis of a phenomenon, the correct theory, and the appropriate model, } \\
\text { (c) Enables students to review the understanding or information they know. }\end{array}$ \\
\hline 2. & The investigative \\
nature of science & $\begin{array}{l}\text { Stimulate students' thinking activities to actively work in "finding out" knowledge individually } \\
\text { or in groups. Reflects the active aspects of investigation in learning that involve students in } \\
\text { the process of scientific methods such as observing, measuring, categorizing, drawing } \\
\text { conclusions, recording data, doing calculations, experimenting, etc. In this category the } \\
\text { scientific literacy analyzed in books is divided into several aspects as follows: } \\
\text { (a) Require students to answer questions using the right subject matter. } \\
\text { (b) Require students to answer questions in graphs and tables. } \\
\text { (c) Require students to answer questions using a calculation formula. }\end{array}$ \\
\hline
\end{tabular}




\begin{tabular}{|c|c|c|}
\hline No & $\begin{array}{l}\text { Category of } \\
\text { Scientific Literacy }\end{array}$ & Description \\
\hline & & $\begin{array}{l}\text { (d) Require students to use reasoning in answering questions } \\
\text { (e) Involving students in laboratory experimental activities or other thinking activities. }\end{array}$ \\
\hline 3. & $\begin{array}{l}\text { Science as a way } \\
\text { of thinking }\end{array}$ & $\begin{array}{l}\text { Describes how science or science scientists "find out". Aspects in this category represent } \\
\text { ways of thinking, reasoning in solving problems, and even reflecting, in which students are } \\
\text { provided with information about how science itself works. In this category the scientific } \\
\text { literacy analyzed in books is divided into several aspects as follows: } \\
\text { (a) Tell how the experiment is carried out like a scientist, } \\
\text { (b) Provides a detailed history of the development of knowledge, } \\
\text { (c) Emphasizes the empirical nature of science and objectivity in science, } \\
\text { (d) Include assumptions that can arise in science, } \\
\text { (e) Shows how the sciences develop with inductive and deductive reasoning. } \\
\text { (f) Providing linkage of cause-and-effect relationship, } \\
\text { (g) Discussing proof with other proof, } \\
\text { (h) Presents the stages of the scientific method and how to solve problems. }\end{array}$ \\
\hline 4. & $\begin{array}{l}\text { Interaction of } \\
\text { science, } \\
\text { technology, and } \\
\text { society }\end{array}$ & $\begin{array}{l}\text { Provide a depiction of the various impacts/applications of science for community. This } \\
\text { category deals with the utilization of science in human life and how scientific technology } \\
\text { can help or worsen the condition of mankind. Besides, it also concerns social problems and } \\
\text { provides an overview of students' future careers. In this category the scientific literacy } \\
\text { analyzed in books is divided into several aspects as follows: } \\
\text { (a) Provide examples of the use of science along with the use of technology to people's } \\
\text { lives, } \\
\text { (b) Give examples of the negative influence of the application of science to technology and } \\
\text { society, } \\
\text { (c) Discusses social problems related to science or technology, and } \\
\text { (d) Provide an overview of careers and professions in science and technology. }\end{array}$ \\
\hline
\end{tabular}

\section{RESULTS AND DISCUSSION}

\subsection{Recapitulation of Observer Agreement Levels}

Table 2. Recapitulation of the Level of Agreement of Observers I and II

\begin{tabular}{|c|c|c|c|c|}
\hline \multirow{2}{*}{ No } & \multirow{2}{*}{ Class } & \multirow{2}{*}{ Book } & \multicolumn{2}{|c|}{ Interrater Agreement } \\
\hline & & & $\%$ & Category \\
\hline 1. & \multirow[t]{2}{*}{ VII } & Book A & 0,94 & Very good \\
\hline 2. & & Book B & 0,97 & Very good \\
\hline 3. & \multirow[t]{2}{*}{ VIII } & Book C & 0,95 & Very good \\
\hline 4. & & Book D & 0,97 & Very good \\
\hline 5. & \multirow[t]{2}{*}{ IX } & Book E & 0,93 & Very good \\
\hline 6. & & Book F & 0,95 & Very good \\
\hline
\end{tabular}


The research results are listed in the table between the two observers, it was found that the level of agreement was classified as very high in each book, this shows that the differences in the results of the observations in books $\mathrm{A}, \mathrm{B}, \mathrm{C}, \mathrm{D}, \mathrm{E}$, and F were not too large between the two observers ranging from $0,97-0,93$. Books that have the highest agreement level are book B and book D of 0,97 ; followed by book $\mathrm{C}$ and book $\mathrm{F}$ amounting to 0,95 ; book $\mathrm{A}$ is 0.94 and the last book $\mathrm{E}$ is 0,93 .

\subsection{Frequency of Scientific Literacy in Textbooks}

In the four categories that are used as a framework for analyzing this textbook, it can be said that $1^{\text {st }}$ category of scientific literacy, which is presenting the latest facts, theories, models, concepts, principles, and laws and knowing students' memories of general knowledge and information are the most dominant in textbooks in Indonesia.

$2^{\text {nd }}$ category and $3^{\text {rd }}$ category of scientific literacy will mostly involve students in activities related to higher student activities. The second category directs students to be more involved in activities that emphasize activities using scientific methods such as observing something, calculating measures accurately, classifying groupings, learning to write conclusions, making observational data records, calculating the results of observations, experimenting on various themes or learning topics.

$3^{\text {rd }}$ category of scientific literacy is an analysis that describes how students are invited to do activities like scientists in making discoveries. The general definition which is then derived in a special indicator in this category emphasizes how the steps of a scientist in experimenting, forming an assumption, looking for scientific evidence and data to see the development of science and the history behind it.

$4^{\text {th }}$ category of scientific literacy is the relationship between the use of science in technology and society (STS) which has the least frequency and is, therefore, the easiest to analyze and categorize. Thus, it is easy to identify the effects of the application of science in society, social problems related to science and technology, as well as an overview of students' future careers related to STS.

Table 3. Distribution lof presentation of scientific literacy in each textbook

\begin{tabular}{|c|c|c|c|c|c|c|c|c|c|c|c|c|c|}
\hline \multirow{3}{*}{$\begin{array}{c}\text { Category of Scientific } \\
\text { Literacy }\end{array}$} & \multicolumn{12}{|c|}{ Occurrence Rate } & \multirow{3}{*}{$\begin{array}{l}\text { Mean } \\
(\%)\end{array}$} \\
\hline & \multicolumn{2}{|c|}{ Book A } & \multicolumn{2}{|c|}{ Book B } & \multicolumn{2}{|c|}{ Book C } & \multicolumn{2}{|c|}{ Book D } & \multicolumn{2}{|c|}{ Book E } & \multicolumn{2}{|c|}{ Book F } & \\
\hline & $\Sigma$ & $\%$ & $\sum$ & $\%$ & $\sum$ & $\%$ & $\Sigma$ & $\%$ & $\Sigma$ & $\%$ & $\Sigma$ & $\%$ & \\
\hline $\begin{array}{l}\text { The knowledge of } \\
\text { science }\end{array}$ & 79 & 56.4 & 22 & 64.7 & 124 & 77.1 & 51 & 55.4 & 73 & 68.9 & 90 & 59.6 & 63.7 \\
\hline $\begin{array}{l}\text { The investigative } \\
\text { nature of science }\end{array}$ & 33 & 23.6 & 7 & 20.6 & 7 & 4.3 & 16 & 17.4 & 14 & 13.2 & 26 & 17.2 & 15.8 \\
\hline $\begin{array}{l}\text { Science as a way of } \\
\text { thinking. }\end{array}$ & 15 & 10.7 & 3 & 8.8 & 19 & 11.8 & 18 & 19.6 & 10 & 9.4 & 23 & 15.2 & 12.7 \\
\hline $\begin{array}{l}\text { Interaction of science, } \\
\text { technology, and } \\
\text { society. }\end{array}$ & 13 & 9.3 & 2 & 5.9 & 11 & 6.8 & 7 & 7.6 & 9 & 8.5 & 12 & 8 & 7.8 \\
\hline Total & 140 & 100 & 34 & 100 & 161 & 100 & 92 & 100 & 106 & 100 & 151 & 100 & 100 \\
\hline
\end{tabular}

\subsection{Percentage of Scientific Literacy in Textbooks in Each Class}

The results of the research presented in the table indicate that the main orientation of science textbooks for junior high schools in Indonesia tends to be more towards the category of "the knowledge of science" and less attention to other categories of scientific literacy. It is stated in the table above that of all the books that have been analyzed, the results are obtained. $63,7 \%$ of the elements in the book belong to $1^{\text {st }}$ category scientific 
knowledge; $15.8 \%$ in $2^{\text {nd }}$ category the nature of the investigation in science; $12.7 \%$ in $3^{\text {rd }}$ category science as a way of thinking and $7.8 \%$ in $4^{\text {th }}$ category science as the interaction between STS.

The percentage of $1^{\text {st }}$ category is the category that most dominates the category of scientific literacy in textbooks. Most of the paragraphs, explanatory images, pictures with annotations and additional information that appear in science textbooks tell of easily recognizable phenomena. This is a condition that seems to have been standardized in every science textbook, not only in Indonesia. Following the results of previous research which showed that the first category or scientific knowledge appeared the most in textbooks, amounting to $65.7 \%$ compared to the other 3 categories [17]. Section of life sciences and chemistry in textbooks are more focused on a collection of scientific knowledge that provides subject matter by presenting many definitions and describing the processes of life. This also follows the results of scientific literacy research in textbooks that have been conducted in Greece, which also shows that first category dominates with a value of $68.5 \%$, so it is concluded that the scientific content in the first category is more dominant than others [18].

When viewed from the facts of education in Indonesia, students memorize more. This is according to the results of the level of scientific literacy proficiency according to PISA (2012), namely the score obtained from Indonesia is at a low level (level 1) from the highest level 6 which indicates that Indonesian students are only able to carry out a one-step procedure (considering facts, terms, principles or the concept of a simple table or graph) [19]. Because students are more focused on science content only, students become less motivated in learning science. So those teachers are expected to carry out learning can further motivate students so that they can master other categories of scientific literacy.

It seems that education in Indonesia places more emphasis on abstract concepts and less on developing active experimentation in learning where these two things should be taught to students proportionally [20]. The dominance of science content in textbooks is seen to be the highest so that science learning in secondary schools in Indonesia emphasizes cognitive aspects rather than developing students' thinking skills. This is in line with the data disclosed, based on the textbooks used. 2nd category and 3rd category is the second and third highest percentage of the total that appears in 6 science books. However, these two categories cannot be used as benchmarks, they will always be the second most because they are determined by the number of pages analyzed. It can be seen in table 5 that this second category in books of class VIII has the third-largest percentage of occurrence, different from the results of books of class VII (Table 4) and books of class IX (Table 6).

$2^{\text {nd }}$ shows that the author of the book does not pay attention to the stages of scientific development as a learning process in accordance with the proportions in the book. Where students must learn to understand that the nature of science includes scientific inquiry, activities in the scientific process, and activities at a higher cognitive level. In the 6 books analyzed, the nature of science written by the author on average invites students to reason uses calculations in answering questions, and invites simple experimental activities that students can do.

$3^{\text {rd }}$ shows that scientific indicators as a way of thinking have contributed to the development of scientific literacy, which is shown in the relationship between observed natural phenomena. It aims to make students have broader insights into seeing the relationship between science and its relation to existing scientific theories. This shows that the authors of the books studied paid less attention to this category. Even though it is very important to build students' thought processes, including their improvement, to achieve this goal, science as a way of thinking must be prioritized in writing textbooks [21].

$4^{\text {th }}$ category is the category with the smallest percentage in each book analyzed in this study. From the percentage of appearance, the books analyzed emphasize the positive impact of STS interactions, but very few show negative impacts, social problems due to the use of science, and community work careers related to science. In the future, textbook writers will be able to show more about the relationship between STS and their problems. So that students are not only fixated on theory but also understand the use of science in society and future careers that can be taken into account by students in choosing a job. 
Table 4. Distribution of themes science literacy percentage for class VII books

\begin{tabular}{|c|c|c|c|c|c|}
\hline \multirow{3}{*}{ Category of Science Literacy } & \multicolumn{4}{|c|}{ Occurrence Rate } & \multirow[t]{3}{*}{ Mean (\%) } \\
\hline & \multicolumn{2}{|c|}{ Book A } & \multicolumn{2}{|c|}{ Book B } & \\
\hline & $\sum$ & $\%$ & $\Sigma$ & $\%$ & \\
\hline The knowledge of science & 79 & 56.4 & 22 & 64.7 & 60.5 \\
\hline The investigative nature of science & 33 & 23.6 & 7 & 20.6 & 22.1 \\
\hline Science as a way of thinking. & 15 & 10.7 & 3 & 8.8 & 9.8 \\
\hline Interaction of science, technology, and society. & 13 & 9.3 & 2 & 5.9 & 7.6 \\
\hline Total & 140 & 100 & 34 & 100 & 100 \\
\hline
\end{tabular}

Table 5. Distribution of themes science literacy percentage for class VIII books

\begin{tabular}{|c|c|c|c|c|c|}
\hline \multirow{3}{*}{ Category of Science Literacy } & \multicolumn{4}{|c|}{ Occurrence Rate } & \multirow[t]{3}{*}{ Mean (\%) } \\
\hline & \multicolumn{2}{|c|}{ Book A } & \multicolumn{2}{|c|}{ Book B } & \\
\hline & $\Sigma$ & $\%$ & $\Sigma$ & $\%$ & \\
\hline The knowledge of science & 124 & 77.1 & 51 & 55.4 & 66.2 \\
\hline The investigative nature of science & 7 & 4.3 & 16 & 17.4 & 10.9 \\
\hline Science as a way of thinking. & 19 & 11.8 & 18 & 19.6 & 15.7 \\
\hline Interaction of science, technology, and society. & 11 & 6.8 & 7 & 7.6 & 7.2 \\
\hline Total & 161 & 100 & 92 & 100 & 100 \\
\hline
\end{tabular}

Table 6. Distribution of themes science literacy percentage for class IX books

\begin{tabular}{|c|c|c|c|c|c|}
\hline \multirow{3}{*}{ Category of Science Literacy } & \multicolumn{4}{|c|}{ Occurrence Rate } & \multirow[t]{3}{*}{ Mean (\%) } \\
\hline & \multicolumn{2}{|c|}{ Book A } & \multicolumn{2}{|c|}{ Book B } & \\
\hline & $\sum$ & $\%$ & $\Sigma$ & $\%$ & \\
\hline The knowledge of science & 73 & 68.9 & 90 & 59.6 & 64.25 \\
\hline The investigative nature of science & 14 & 13.2 & 26 & 17.2 & 15.2 \\
\hline Science as a way of thinking. & 10 & 9.4 & 23 & 15.2 & 12.3 \\
\hline Interaction of science, technology, and society. & 9 & 8.5 & 12 & 8 & 8.25 \\
\hline Total & 106 & 100 & 151 & 100 & 100 \\
\hline
\end{tabular}

The results obtained from each book analyzed in each class showed that in first category, class VIII contained more about $66.2 \%$, which was then followed respectively by the results of class XI of $64.25 \%$ and class VII of 60 , $5 \%$. Whereas in the second and third categories, respectively, books in class VII and IX were greater in the second category than in the third category, namely
$22.1 \%$ and $15.2 \%$. Different results can be seen from class VIII, which shows the third category is more than the second category as much as $10.9 \%$. The fourth category is the category in which each book in each class has the least proportion compared to the other categories, namely class VII at $7.6 \%$; class VIII is $7.2 \%$ and class IX is $8.25 \%$. 
Overall, the results of the six textbooks analyzed to reflect the content of scientific literacy in their books, but the proportion of the emergence of scientific literacy from each category that is used as an indicator is not yet balanced because there is only one category that looks the most dominant the scientific knowledge. This follows from previous research having the results of analytical research on nine science textbooks in junior high schools in Indonesia, both grades VII, VIII, and IX reflect the scientific literacy, but the percentage of the emergence of each category of scientific literacy presented is not balanced only one category. The dominant one is a first category about the knowledge of science [22]. This study also agrees with the statement that text books play a major role in shaping science learning activities to date, but much popular science curriculum series do not include an active learning approach and do not devote sufficient coverage to the problem of STS interaction [23,24].

Most of the textbooks through this analysis do not seem to really unify the 4 categories with each other as a whole so that it appears that the science content (cognitive section) is separated from the nature of science used to develop students' thinking skills and scientific method skills such as scientists. Textbooks are supposed to bring together all aspects related to science. If we are to give our children a solid foundation in understanding scientific literacy, then junior high school science programs must control the heavy reliance of students and teachers on the use of textbooks as the primary source of learning or revising the preparation of subsequent science textbooks with include more teaching strategies and a more varied learning approach, which more represents the themes of scientific literacy [25]. On the other hand, teachers must play a role as learning facilitators in analyzing textbooks to find deficiencies, problems, and limitations of textbooks that their students use as learning guides [26].

There needs to be attention from various parties so that indicators of scientific literacy can be further developed in the next textbook with the aim that a complete picture of science can be shown to students. This aims to make students more motivated to study science in detail and in depth, develop their thinking skills, so that they are considered capable of answering problems related to STS relationships, and able to follow the challenges of the technology-based era. The role of researchers is also important in science education to study the entire contents of SMP science textbooks in detail in finding and minimizing deficiencies, given the central role played by these researchers in the curriculum which is crucial enough to be able to make changes. Science teachers must also take part in sorting out textbooks before adopting certain textbooks that support their teaching. By weighing the appropriate book content, considering the relationship of textbooks with the characteristics and interests of their students, and containing enough technology and broader insights into student learning so that they can get a picture of their students' future careers.

\section{CONCLUSION}

The findings of the study show that the science textbooks of junior high schools in Indonesia are good at covering scientific literacy themes according to the 2013 curriculum applied, although the emphasis is more on "the knowledge of science" category while other categories have less equal proportions or even unbalanced. The categories "interactions between science, technology, and society", overall, have less dominance, suggesting that textbooks in general need emphasize these aspects more. This analysis also illustrates that the science textbooks that have been analyzed are still imbued with a positivistic point of view about science. However, the ideal book does not necessarily suit the conditions of students in school, so the selection of textbooks must still be adjusted to the existing conditions, especially the conditions of students. If the right textbook is chosen, it is hoped that it will further improve understanding of science which in turn can increase scientific literacy. In this case, with the above analysis, the need to change the structure and character of school textbooks with regard to aspects of scientific literacy needs to be done.

\section{REFERENCES}

[1] N. R, Y. Rinanto, M. Ramli, Scientific Literacy Profile in Biological Science of High School Students, Jurnal Pendidikan Biologi Indonesia 5(1) (2019) 9-16. DOI: https://doi.org/10.22219/jpbi.v5i1.7080

[2] N.G. Lederman, J.S. Lederman, A. Antink, Nature of Science and Scientific Inquiry as Contexts for The Learning of Science and Achievement of Scientific Literacy, International Journal of Education in Mathematics 1(3) (2013) 138-147. DOI: https://doi.org/10.18404/ijemst.19784

[3] OECD, The PISA 2003 Assessment Framework: Mathematics, Reading, Science and Problem Solving Knowledge and Skills, OECD Publishing, 2003. 
[4] C. J. Wenning, Assessing Inquiry Skills as A Component Of Scientific Literacy, Journal of Physics Teacher Education 4(2) (2007) 21-24.

[5] J. Holbrook, M. Rannikmae, The Nature of Science Education for Enhancing Scientific Literacy, International Journal of Science Education 29(11) (2007) 275-288.

DOI: https://doi.org/10.1080/09500690601007549

[6] OECD, Programme for International Student Assessment (PISA) Result from PISA 2018 specific country Indonesia, OECD Publishing, 2019

[7] I.N. Fatmawati, S. Utari, Penerapan Levels of Inquiry untuk Meningkatkan Literasi Sains Siswa SMP Tema Limbah Dan Upaya Penanggulangannya, Edusains 7(2), 2016, pp. 151159. DOI: https://doi.org/10.15408/es.v7i2.1750

[8] N.S. Istiqomah, I.M. Sari, W. Liliawati, Literasi Sains Siswa Kelas 9 SMP Kota Bandung Pada Konteks Sumber Daya Alam, in: Prosiding Semnas Pendidikan IPA, Pascasarjana UM, 2016, pp. 387393.

[9] M. Koppal, A. Caldwell, Meeting The Challenge of Science Literacy: Project 2061 Efforts to Improve Science Education, Cell Biology Education 3(1), (2004) 28-30. DOI: https://doi.org/10.1187/cbe.03-10-0016

[10] A. Ahtineva, Textbook Analysis in The Service of Chemistry Teaching, Universitas Scientiarum 10 (2005) $25-33$.

[11] R.E. Yager, Science-technology-society as reform, School Science and Mathematics 93(3) (1993) 145151. DOI: https://doi.org/10.1111/j.19498594.1993.tb12213.x

[12] S. Irez, Nature of Science As Depicted In Turkish Biology Textbooks, Science Education 93(3) (2008) 422-447. DOI: https://doi.org/10.1002/sce.20305

[13] N. Maturradiyah, A. Rusilowati, Analisis Buku Ajar Fisika SMA Kelas XII Di Kabupaten Pati Berdasarkan Muatan Literasi Sains, UPEJ (Unnes Physics Education Journal) 4(1) (2015) 16-20. DOI: https://doi.org/10.15294/upej.v4i1.4731
[14] M. Slapnicar, Critical Analysis of Science Textbooks, CEPS Journal (2014) 137-141. DOI: https://doi.org/10.1007/978-94-007-4168-3

[15] E.L. Chiappetta, D.A Fillman, G.H Sethna, A Method to Quantify Major Themes of Scientific Literacy in Science Textbooks, Journal of Research in Science Teaching 28(8) (1991) 713-725. DOI: https://doi.org/10.1002/tea.3660280808

[16] J. Wilkinson, A quantitative analysis of physics textbooks for scientific literacy themes, Research in Science Education 29(3) (1999) 385-399. DOI: https://doi.org/10.1007/BF02461600

[17] E.L Chiappetta, G.H Sethna, D.A Fillman, A Quantitative Analysis of High School Chemistry Textbooks for Scientific Literacy Themes and Expository Learning Aids, Journal of Research in Science Teaching 28(10) (1991) 939-951. DOI: https://doi.org/10.1002/tea.3660281005

[18] K. Spyros, S. Dimitris, H. Krystallia, A quantitative analysis of greek physics textbooks with respect to scientific literacy, in: Conference: IOSTE International Meeting, vol. 1, Kyungpook National University, Korea, 2007, pp. 1-11.

[19] OECD, PISA 2012 Assessment and Analytical Framework: Mathematics, Reading, Science, Problem Solving and Financial Literacy, OECD Publishing, 2013.

[20] T.E Yulianti, A. Rusilowati, Analisis Buku Ajar Fisika SMA Kelas XI Berdasarkan Muatan Literasi Sains Di Kabupaten Tegal, Unnes Physics Education Journal 3(2) (2014) 68-72. DOI: https://doi.org/10.15294/upej.v3i2.3597

[21] M.N Erdogan, F. Koseoglu, Analysis of High School Physics, Chemistry and Biology Curriculums in Terms of Scientific Literacy Themes, Educational Sciences: Theory \& Practice 12(4) (2012) 2899-2904.

[22] A. Rusilowati, Analisis buku ajar ipa yang digunakan di semarang berdasarkan muatan literasi sains, in: Proceeding Seminar Nasional Konservasi dan Kualitas Pendidikan, Universitas Negeri Semarang, 2014, pp. 1-10.

[23] E.L Chiapetta, G.H Sethna, D.A Fillman, Do Middle School Life Science Textbooks Provide A Balance of Scientific Literacy Themes, Journal of 
Research in Science Teaching 30 (7), (1993) 787797. DOI: https://doi.org/10.1002/tea.3660300714

[24] A.T Lumpe, J. Beck, A Profile of High School Biology Textbooks Using Scientific Literacy Recommendations, The American Biology Teacher 58(3) (1996) 147-153. DOI: https://doi.org/10.2307/4450103

[25] D. Elliott, K. Nagel, A. Woodward, Scientific Illiteracy in Elementary School Science Textbook
Programmes, Journal of Curriculum Studies 19(1) (1987) 73-76. DOI: https://doi.org/10.1080/0022027870190108

[26] L. Haggarty, B. Pepin, An Investigation of Mathematics Textbooks and Their Use in English, French and German Classrooms: Who Gets An Opportunity To Learn What, British Educational Research Journal 28(4) (2002) 567-590. DOI: https://doi.org/10.1080/0141192022000005832 